\title{
Trend detection in climate data for north western zone of Tamil $\mathrm{Nadu}$
}

\author{
A. VALLIAMMAI, D. RAMYASRI, S. SELVAKUMAR AND V. MANIVANNAN
}

Article Chronicle :

Received :

28.01.2016;

Revised :

16.04.2016;

Accepted :

29.04.2016

Key Words : Temporal, Trend, Rainfall, MannKendall test
ABSTRACT : The subject of trend detection in climate data has received a great deal of attention lately, especially in connection with the anticipated changes in global climate. Precipitation trend analysis, on different scales, has been of great concern during the past century because of the attention given to global climate change by the scientific community. In a study on temporal trends analysis of annual and season rainfall values were investigated in drought prone areas of North Western Zone of Tamil Nadu. For this purpose, rainfall value collected from 33 rain gauge stations over a period of 28 year (1986-2013) were used and statistically significant rainfall trends in the seasonal and annual time basis were detected using nonparametric Mann-Kendall (MK) tests at the 5 per cent significant level. The results of this study indicated that the rainfall trends for some rain gauge locations were increasing however, for some sites, they showed a decreasing trend. The most number of stable trends on an annual time scale occurred at Thammampatti with a maximum $Z$ value but stable trends was observed in it. On the annual time scale, North Western zone revealed the highest positive trend $(2.2 \mathrm{~mm}$ per year). On the other hand, Thopiyardam showed the highest decreasing rainfall trend of about $-3.19 \mathrm{~mm}$ per year. In general, the performances and abilities of the MK tests were consistent at the verified significant level.

HOW TO CITE THIS ARTICLE : Valliammai, A., Ramyasri, D., Selvakumar, S. and Manivannan, V. (2016). Trend detection in climate data for north western zone of Tamil Nadu. Asian J. Environ. Sci., 11(1): 24-29, DOI: 10.15740/HAS/AJES/11.1/24-29.
Author for correspondence :

\section{A. VALLIAMMAI}

Department of Soil and

Water Conservation

Engineering, Water

Technology Centre

(T.N.A.U.), COIMBATORE

(T.N.) INDIA

See end of the article for

Coopted authors' 